\title{
TRABALHO, POLÍTICA, FORMAÇÃO E EMANCIPAÇÃO HUMANA EM MARX E LUKÁCS.
}

\author{
WORK, POLITICS, FORMATION AND HUMAN EMANCIPATION \\ IN MARX AND LUKACS.
}
TRABAJO, POLITICA, FORMACIÓN Y EMANCIPACIÓN HUMANA
EN MARX Y LUKÁCS.

\section{Hormindo Pereira Souza Junior $^{1}$ Daniel Handan Triginelli ${ }^{2}$}

\section{RESUMO}

Neste artigo discutiremos as categorias trabalho, política, formação e emancipação humana em Marx e Lukács. A partir da categoria trabalho, buscaremos compreender a política, a formação e a emancipação humana como fundamentos necessários à formação do ser social. A partir do salto ontológico produzido pela categoria trabalho, verifica-se historicamente a concretização das condições e possibilidades ao desenvolvimento dos demais complexos fundamentais à formação do ser social. Através do afastamento das barreiras naturais, Lukács, na esteira de Marx, demonstra como a dupla transformação, mediada pelo trabalho no metabolismo do homem com a natureza, se dá na formação material/social/histórica do ser humano, tornando-se a base de toda sua práxis social, portanto, de sua emancipação. Problematizaremos também acerca do "caráter antisocial" da propriedade privada e do Estado, portanto, da política para descortinar a origem dos problemas sociais e de sua essência. A política é, segundo Marx, uma atividade meio, datada historicamente e instrumental. É algo que há de ser superado. Esta concepção da política, e do Estado, recusa o entendimento de que ela constitui uma dimensão do humano e do social de forma permanente e estrutural.

\section{PALAVRAS-CHAVE: Trabalho; Formação; Estado; Política; Emancipação Humana.}

\section{ABSTRACT}

This article we discuss the categories work, politics, education and human emancipation in Marx and Lukacs. As from the work category, we will seek to understand the policy, training and human emancipation as foundations necessary to the formation of social being. Starting from the ontological leap produced by work category, historically-checks the implementation of the conditions and possibilities for the development of other fundamental complex to the formation of social being. Through the removal of natural barriers, Lukács, in the wake of Marx, demonstrates how the double transformation mediated by work in the human metabolism with nature, occurs in the training materials / social / historical human, becoming the basis of all its social praxis therefore their emancipation. We will also discuss about "antisocial character" Private Property and the State, therefore the policy to uncover the origin of social problems and its essence. Politics is, according to Marx, one half activity, historically dated and instrumental. It's something that has to be

\footnotetext{
${ }^{1}$ Doutorado em História e Filosofia da Educação - Pontifícia Universidade Católica de São Paulo (PUCSP). Professor associado - Universidade Federal de Minas Gerais (UFMG) - Belo Horizonte, MG - Brasil Email: hormindojunior@gmail.com.

${ }^{2}$ Doutorado em Educação -Universidade Federal de Minas Gerais (UFMG). Professor substituto do Centro Federal de Educação Tecnológica de Minas Gerais (CEFET-MG) -, Belo Horizonte, MG - Brasil Email: daniellic.bchistoria@yahoo.com.br>
}

Submetido em: 07/11/2015 - Aceito em: 28/06/2016

\section{(C) ETD-Educação Temática Digital Campinas, SP v.19 $\quad$ n.1 $\quad$ p. 258-282 jan./mar. 2017}


overcome. This conception of politics, and the state, rejects the understanding that it is a dimension of human and social permanently and structurally.

KEYWORDS: Work; Formation; State; Politics; Human emancipation.

RESUMEN

En este artículo discutiremos las categorías trabajo, política, formación y emancipación humana en Marx y Lukács. A partir de la categoría trabajo, buscaremos comprender la política, la formación y la emancipación humana como fundamentos necesarios a la formación del ser social. A partir del salto ontológico producido por la categoría trabajo, se verifica históricamente la concretización de las condiciones y posibilidades al desarrollo de los demás complejos fundamentales a la formación del ser social. A través del alejamiento de las barreras naturales, Lukács, en la esteira de Marx, demuestra como la doble transformación, mediada por el trabajo en el metabolismo del hombre con la naturaleza, se da en la formación material/social/histórica del ser humano, haciéndose la base de toda su práxis social, por lo tanto, de su emancipación. Problematizaremos también acerca del carácter antisocial de la propiedad privada y del Estado, por lo tanto, de la política para descortinar el origen de los problemas sociales y de su essência. La política es, según Marx, una actividad medio, datada históricamente e instrumental. Es algo que hay de ser superado. Esta concepción de la política, y del Estado, rechaza la comprensión de que ella constituye una dimensión del humano y del social de forma permanente y estructural.

PALABRAS-CLAVE: Trabajo; Formación; Estado; Política; Emancipación Humana.

\section{MARX E A CENTRALIDADE DO TRABALHO NA FORMAÇÃO DO SER SOCIAL.}

Em relação a centralidade do trabalho na obra marxiana, atualmente, parece existir, em certa medida, um frágil consenso (quando existe) nos ciclos que se debruçam em realizar estudos a partir do legado do filosofo alemão. Todavia, essa centralidade da categoria trabalho hoje, ainda não é unanime como outrora já não o fora. Neste sentido, cabe enaltecer os estudos a partir da apreensão e compreensão teórica realizados por György Lukács nessa direção. É sabido que esse autor tem, em sua biografia, momentos marcantes no seu desenvolvimento intelectual, o que o torna um autor complexo e deixa esse percurso com trechos importantes e extremamente difíceis de serem percorridos. Não cabe aqui discutir os caminhos que esse autor percorreu até sua maturidade marxista. Nosso objetivo se resguarda na reafirmação propositiva da condição fundamental do trabalho nos processos de formação e emancipação humana. Por isso, nesse artigo, nos propomos a examinar a decisiva apreensão e compreensão da obra marxiana nos textos do próprio Marx e na imanente reorientação promovida por Lukács, no que diz respeito a centralidade do trabalho como categoria ontológica fundante e central no processo de auto constituição e desenvolvimento do ser social.

Lukács, após sua chegada a Moscou na década de 30 do século passado, foi designado a trabalhar no Instituto Marx-Engels juntamente com David Riazanov. Nesse período, desempenhou a tarefa de organização dos textos de Marx. Consequentemente,

(C) ETD- Educação Temática Digital Campinas, SP $\quad$ v.19 $\quad$ n.1 $\quad$ p. 258-282 jan./mar. 2017 
Lukács tem contato com obras inéditas do autor, em especial, destacamos os Manuscritos econômicos-filosóficos. Esse texto produz forte impacto no pensamento do filósofo húngaro, a partir de sua leitura Lukács apreende e compreende o fio condutor da filosofia de Marx, que este inicia em sua juventude e o aprofunda no decorrer de seu desenvolvimento. Diz ele:

\begin{abstract}
"Apesar de não existir, em Marx, nenhum tratamento autônomo de problemas ontológicos; ele jamais se preocupa em determinar o lugar desses problemas no pensamento, em defini-los com relação à teoria do conhecimento, à lógica etc. de modo sistemático ou sistematizante". (LUKÁCS; 2012; 281).
\end{abstract}

Isso quer dizer que, como o autor demonstra no capítulo sobre os princípios ontológicos fundamentais de Marx, em sua obra de maturidade para uma ontologia do ser social, o pensamento marxiano não sofre de ruptura entre sua fase inicial (juventude) e sua fase madura. Marx demonstra desde a carta que escreve ao seu pai, com dezenove anos, para justificar as razões que o levará a cursar filosofia e não direito, que a questão central que o inquieta diz respeito a como do ser natural, do ser orgânico se dá e desenvolve o ser social. Ou dito de outra maneira, como do "macaco" se dá o homem, ou mesmo: como o homem se socializa se humaniza.

Neste sentido, Marx identifica que o homem para se constituir enquanto ser que se põe no mundo, depende de uma relação transformadora e eterna com a natureza. Que no ato de transformar as coisas existentes na realidade em sua forma natural, em coisas qualitativamente novas e com valor de uso para a satisfação de suas necessidades imediatas, esse ser transforma a si mesmo e sua condição de existência. Contudo, esta relação de dupla transformação, somente se realiza mediada por uma categoria, uma inflexão decisiva, posta por Marx, na história da filosofia: o trabalho. Somente o ser que trabalha é capaz de transformar a natureza e com isso a si mesmo, o que o eleva, no decorrer do desenvolvimento histórico, a condição de alterar sua forma de vida e existência. Nesse sentido diz Marx:

Pois primeiramente o trabalho, a atividade vital, a vida produtiva mesma aparece ao homem apenas como meio para a satisfação de uma carência, a necessidade de manutenção da existência física. A vida produtiva é, porém, a vida genérica. É a vida engendradora de vida. No modo (Art) da atividade vital encontra-se o caráter inteiro de uma species, seu caráter genérico, e a atividade consciente livre e o caráter genérico do homem. A vida mesmo aparece como meio de vida (MARX; 2009; 84).

(C) ETD-Educação Temática Digital Campinas, SP v.19 $\quad$ n.1 $\quad$ p. 258-282 jan./mar. 2017 
Desta forma, é possível compreender que através do trabalho e seus resultados reais, o ser afasta-se das barreiras naturais que o limita e constitui uma realidade cada vez mais histórica, social e humana. É com as transformações postas pelo e no trabalho que o homem proporciona a formação humana e faz a história. A partir das possibilidades existentes na realidade, posta em sua condição primária, se oferecem as possibilidades de conhecer suas propriedades e transforma-las. Ou seja, o conhecer está na materialidade concreta existente nas possibilidades efetivamente postas pela realidade. O que a ideia é capaz de produzir, é a organização epistemológica desse acumulo da prática material, real ao longo da história. Dessa maneira Marx e Engels superam o idealismo e lançam as bases do materialismo histórico ao afirmarem que:

Os pressupostos de que partimos não são arbitrários, dogmas, mas pressupostos reais, de que só se pode abstrair na imaginação. São os indivíduos reais, sua ação e suas condições materiais de vida, tanto aqueles por eles já encontradas como as produzidas por sua própria ação. Esses pressupostos são, portanto, constatáveis por via puramente empíricas (MARX, ENGELS; 2007; 86-7).

Nas teses Ad Feuerbach, os autores demonstram, para além dos equívocos presentes na filosofia idealista, a ausência, ora de história, ora de materialidade em Feuerbach, ou seja, os limites do materialismo deste. Ao mesmo tempo em que reafirmam e demonstram a centralidade do trabalho no processo de auto constituição ou formação humana e sua eterna e insuperável necessidade para a manutenção e reprodução da existência humana em sua constituição material e histórica. Dizem os autores:

\footnotetext{
Na medida em que Feurbach é materialista, nele não se encontra a história, e na medida em que toma em consideração a história ele não é materialista. Nele, materialismo e história divergem completamente, o que aliás se explica pelo que dissemos até aqui. Em relação aos alemães, que se consideram isentos de pressupostos [Voraissetzungslosen], devemos começar por constatar o primeiro pressuposto de toda a existência humana e também, portanto, de toda a história, a saber, o pressuposto de que os homens têm de estar em condições de viver para poder "fazer história". Mas, para viver, precisa-se, antes de tudo, de comida, bebida, moradia, vestimenta e algumas coisas mais. O primeiro ato histórico é, pois, a produção dos meios para a satisfação dessas necessidades, a produção da própria vida material, e este é, sem dúvida, um ato histórico, uma condição fundamental de toda a história, que ainda hoje, assim como há milênios, tem de ser cumprida diariamente, a cada hora, simplesmente para manter os homens vivos (MARX, ENGELS; 2007, 32-3).
}

Já em sua obra máxima ou, como alguns gostam de intitular, obra de maturidade de Marx, o capital, o filósofo alemão reafirma sua base filosófica materialista ontológica, o que o afasta de qualquer concepção economicista como por muitos é rotulado, da centralidade do trabalho no processo de formação humana. Ele o faz ao reafirmar que o homem se realiza pelo trabalho. Nesse sentido, para executá-lo, ele primeiro o planeja no plano ideal,

(C) ETD-Educação Temática Digital Campinas, SP v.19 $\quad$ n.1 $\quad$ p. 258-282 jan./mar. 2017 
todavia, esse projeto na cabeça, não passa de subjetividade não posta. Para existir e constituir algo qualitativamente novo em relação a natureza é preciso que o homem, em um processo continuo e inseparável, se efetive e objetive na realidade o que já existe teleologicamente em sua ideia. Isto só é possível, quando o ser se coloca em atividade, e a transformar pelo trabalho a coisa natural em coisa necessária à sua existência. Ou seja, uma atividade com um fim, uma finalidade posta no plano do real. Isso quer dizer, a soma do esforço físico do ser praticado por seus membros corporais somado ao intelecto. Como resultado, se chega a produção de algo que tem como característica uma finalidade útil ao homem, um valor de uso. Isto é o que difere o humano de todas as demais espécies naturais, isso é o que possibilita o homem a continuamente produzir a história e construir o seu próprio mundo. Sobre isso nos diz Marx:

O trabalho é, antes de tudo, um processo entre homens e a natureza, processo este em que o homem, por sua própria ação, medeia, regula e controla seu metabolismo com a natureza. Ele se confronta com a matéria natural como com uma potência natural [Naturmacht]. Afim de se apropriar da matéria natural de uma forma útil para sua própria vida, ele põe em movimento as forças naturais pertencentes a sua corporeidade: seus braços e pernas, cabeça e mãos. Agindo sobre a natureza externa e modificando-a por meio desse movimento, ele modifica, ao mesmo tempo, sua própria natureza. Ele desenvolve as potências que nela jazem latentes e submete o jogo de suas forças a seu próprio domínio. Não se trata, aqui, das primeiras formas instintivas, animalescas [tierartig], do trabalho. Um incomensurável intervalo de tempo separa o estágio em que o trabalhador se apresenta no mercado como vendedor de sua própria força de trabalho daquele em que o trabalho humano ainda não se desvencilhou de sua forma instintiva. Pressupomos o trabalho numa forma em que ele diz respeito unicamente ao homem. Uma aranha executa operações semelhantes às do tecelão, e uma abelha envergonha muitos arquitetos com a estrutura de sua colmeia. Porém, o que desde o início distingue o pior arquiteto da melhor abelha é o fato de que o primeiro tem a colmeia em sua mente antes de construí-la com cera. No final do processo de trabalho, chega-se a um resultado que já estava presente na representação do trabalhador no início do processo, portanto, um resultado que já existia idealmente. Isso não significa que ele se limite a uma alteração de forma do elemento natural; ele realiza neste último, ao mesmo tempo, seu objetivo, que ele sabe que determina, como lei, o tipo e o modo de sua atividade e ao qual ele tem de subordinar a sua vontade. E essa subordinação não é um ato isolado. Além do esforço dos órgãos que trabalham, a atividade laboral exige a vontade orientada a um fim, que se manifesta como atenção do trabalhador durante a realização de sua tarefa, e isso tanto mais quanto menos esse trabalho, pelo seu próprio conteúdo e pelo modo de sua execução, atrai o trabalhador, portanto, quanto menos este último usufrui dele como jogo de suas próprias forças físicas e mentais. (MARX; 2013; 255-6).

\section{(C) ETD-Educação Temática Digital Campinas, SP v.19 $\quad$ n.1 $\quad$ p. 258-282 jan./mar. 2017}


A partir desta abordagem marxiana é possível apreender e compreender a potência daquilo que Lukács expôs e denominou de "Renascimento do Marxismo". Ou seja, ele lança luz sobre o fio condutor da teoria social elaborada pelo filósofo alemão, teoria social pautada sobre as bases de uma ontologia do ser social. Como se observou, Marx, ao longo de todas as etapas que compõe sua produção teórica, sempre se manteve nas solidas bases ontológicas por ele desenvolvida, por essa inflexão por ele posta na filosofia: uma ontologia do trabalho. Ou seja, o trabalho como mediação na eterna relação de dupla transformação do homem com a natureza, a categoria que funda o ser social. Ao mesmo tempo em que ela é fundante é, também, a categoria central que possibilita todo o desenvolvimento material que se estabelece ao longo da história suas relações mais complexas com a realidade social. Isso quer dizer que: ela cria, a partir da concretude existente no mundo e das relações consequentes desse desenvolvimento que se dá em torno da produção, as condições adequadas de vida e reprodução material da sua própria existência.

\section{TRABALHO E FORMAÇÃO HUMANA NA ONTOLOGIA DO SER SOCIAL DE GYÖRGY LUKÁCS.}

Lukács, com os estudos que desenvolve sobre a teoria social de Karl Marx, a partir da década de 30 do século passado, quando toma contanto com os textos inéditos no Instituto Marx-Engels em Moscou, nos oferece três importantes contribuições para repensar os caminhos tomados pelo movimento comunista mundial até então e para uma reapreensão e recompreensão da perspectiva original desenvolvida por Karl Marx.

Os estudos lukacsianos nos permite apontar para três contribuições fundamentais: primeiro, evidenciar, explicitar: a problemática que envolve a centralidade da categoria trabalho; a questão das relações entre o ser orgânico, inorgânico e social. A problematização das relações entre trabalho e natureza, portanto, apontando para as questões que envolvem os processos de crescente socialização da natureza através do trabalho. A partir dos estudos de Lukács, podemos problematizar em novas bases as questões que envolvem o problema da objetivação do ser social apontando para os processos de estranhamentos objetivados pela sociabilidade no interior da "propriedade privada" e para além dessa. Portanto, nos coloca os limites da sociabilidade posta pela "propriedade privada" para a plena humanização do ser social, da natureza, portanto, da liberdade humana plena.

Segundo, com a leitura de Lukács compreendemos melhor a problemática que envolve as relações entre ontologia e epistemologia nos processos de produção e
(C) ETD- Educação Temática Digital
Campinas, SP
v.19 n.1
p. $258-282$
jan./mar. 2017 
reprodução social dos conhecimentos - a questão do método. Terceiro, Lukács nos possibilita problematizar o conteúdo ontonegativo presente na política em Marx. A compreensão da perspectiva ontonegativa da política em Marx nos permite entender que o filósofo alemão não descarta em momento algum a importância da política, todavia, ela deve ser tratada de forma a proporcionar a autêntica liberdade humana. Ou seja, a necessidade da revolução política ter alma social, caminhar em direção a uma revolução social. Fundamental para a conquista da emancipação humana plena.

Ficamos, por enquanto, apenas na problematização do primeiro ponto: a centralidade do trabalho no processo de formação humana. Para o filósofo húngaro, a obra marxiana não deixa dúvidas em relação a centralidade do trabalho como a categoria fundamental que torna possível a produção e reprodução da vida humana. Essa, é a atividade primeira, necessária, natural e eterna do homem com a natureza, nesse sentido, o trabalho é a relação, mediação concreta que proporciona a ação do homem em objetivar-se e pôr-se no mundo. É por essa mediação que o homem avança em seu domínio sobre o natural e cria sua possibilidade de emancipação em relação as suas necessidades naturais. Mesmo que essa emancipação, ao entendimento de Lukács, não seja total, integral, pois ela em suas bases mais longínquas, sempre estará presente. É por meio do trabalho que o ser se objetiva no mundo e que se auto constitui enquanto ser objetivo, ser social.

O aspecto positivo do trabalho está em si, no fato de o produtor entrar em contanto com o resultado de sua objetivação. Nesse sentido, representa dizer que o produtor tira de si, se objetiva, se aliena na realidade, no mundo. Essa objetivação é algo qualitativamente novo em relação ao natural e, a partir dele, outros complexos (linguagem, ideologia são exemplos) são passiveis de surgimento como elementos da condição social que vai se estabelecendo historicamente ao longo do processo. Esse processo culmina na sociedade organizada pelos parâmetros da propriedade privada dos meios de produção, modelo ao qual, é a dimensão do estranhamento que se sobrepõe e inverte o caráter positivo do trabalho.

Ao citar a passagem de Marx em "O Capital", onde o filósofo apresenta o processo de trabalho em sua totalidade em três momentos: "Os momentos simples do processo de trabalho são, em primeiro lugar, a atividade orientada a um fim, ou o trabalho propriamente dito; em segundo lugar, seu objeto e, em terceiro, seus meios" (MARX; 2013; 256). No aspecto primeiro, Marx, conforme elucida Lukács, está apresentando a teleologia humana, a capacidade de o homem agir em direção ao pôr como finalidade. Nesse sentido,

\section{(C) ETD-Educação Temática Digital Campinas, SP v.19 $\quad$ n.1 $\quad$ p. 258-282 jan./mar. 2017}


a teleologia, em sua essência, é uma categoria posta: todo processo teleológico implica o pôr de um fim e, portanto, numa consciência que põe fins. Pôr, nesse contexto, não significa, portanto, um mero elevar-à-consciência, como acontece com outras categorias e especialmente com a causalidade; ao contrário, aqui, com o ato de pôr, a consciência dá início a um processo real, exatamente ao processo teleológico. Assim, o pôr tem, nesse caso, um caráter irrevogavelmente ontológico (LUKÁCS; 2013; 48).

Dito isto, o pôr teleológico representa uma ruptura com o processo natural de desenvolvimento, pois estando presente no ato de trabalhar é algo qualitativamente novo e diferente em relação ao natural, pois apresenta uma intencionalidade. Ou seja, uma elaboração ideal que se objetiva, tendo em si, uma intencionalidade.

Neste sentido, o trabalho se torna todo o modelo da práxis social humana, pois o pôr teleológico reúne um conjunto de conhecimentos sobre os nexos causais presentes em situações cotidianas. Lukács, ao identificar isso, estabelece debate com toda a filosofia externa e interna ao marxismo, já que Marx submeteu a possibilidade da teleologia existir, apenas no interior do ato de trabalho. Outras correntes filosóficas, mesmo identificando a teleologia, sempre a elevaram a condição de movedora da realidade, seja a concepção religiosa criando um ser consciente (Deus) que rege todas as coisas, ou filosofias mais maduras e consistentes como as de Aristóteles e Hegel, em especial este último, ao eleger a teleologia como motor da história. Esses equívocos estão relacionados a negação do acaso e a necessidade de se atribuir um sentido à vida. A esse respeito, diz Lukács:

Não é, pois, de modo algum surpreendente que grandes pensadores fortemente orientados para a existência social, como Aristóteles e Hegel, tenham apreendido com toda a clareza o caráter teleológico do trabalho. Tanto é assim que suas análises estruturais precisam apenas ser ligeiramente complementadas e não necessitam de nenhuma correção de fundo para manter ainda hoje sua validade. $O$ verdadeiro problema ontológico, porém, é que o tipo de pôr teleológico não foi entendido - nem por Aristóteles nem por Hegel - como algo limitado ao trabalho (ou mesmo, num sentido ampliado, mas ainda legítimo, à práxis humana em geral) (LUKÁCS; 2013; 47).

Sobre o acaso, Lukács procura demonstrar como essa é uma questão cara a filosofia desde a filosofia clássica com Aristóteles. Por esta razão, ele apresenta a relevância da questão envolvendo a relação entre teleologia e causalidade. "Aristóteles distingue, no trabalho, dois componentes: o pensar (nóesis) e o produzir (poíesis). Através do segundo o fim chega à sua realização" (LUKÁCS; 2013; 52-3). Aristóteles já demonstrava a necessidade em conhecer a causalidade posta pela realidade, todavia encontrava problemas no desenvolvimento dessa tese no que se refere as causalidades é os fins para ação. Com

(C) ETD-Educação Temática Digital Campinas, SP v.19 $\quad$ n.1 $\quad$ p. 258-282 jan./mar. 2017 
efeito, tal essência consiste nisso: um projeto ideal alcança a realização material, o pôr pensado de um fim transforma a realidade material, insere na realidade algo material que, no confronto com a natureza, representa algo de qualitativamente e radicalmente novo. [...] Nesse sentido, podemos dizer que Aristóteles foi o primeiro a reconhecer, do ponto de vista ontológico, o caráter dessa objetividade, inconcebível partindo da "logica" da natureza. (LUKÁCS; 2013; 53).

Dessa forma, para se alcançar o fim, conhecer as causalidades é tarefa fundamental. A partir da generalização desse procedimento, Lukács chama atenção, de neste processo, estar localizada a gênese da ciência. Por essa razão, Lukács, ao tratar da relação entre ciência e trabalho, demonstra como a ciência é uma consequência da generalização do conhecimento produzido, adquirido no processo de trabalho, isso sendo possível, através da investigação dos meios.

Desse processo, Lukács chama atenção para o desenvolvimento da consciência neste continuo percurso de auto constituição da formação humana. Lukács ressalta, que somente o ser que trabalha e pelo seu ato de trabalho, produz conhecimento e transforma o natural. Somente ele é capaz de constituir consciência sobre as coisas e situações que o cercam, pois é o único ser capaz de superar a simples adaptação ao meio. "A realização como categoria da forma de ser mostra, ao mesmo tempo, uma importante consequência: a consciência humana, com o trabalho, deixa de ser, em sentido ontológico, um epifenômeno" (LUKÁCS; 2013; 62). Dessa consciência, se estabelece a categoria alternativa e através dela, se põe o momento de decisão da consciência, o humano passa a se afastar da condição natural e dos demais animais da natureza por sua possibilidade e capacidade de decisão.

Somente no trabalho, no pôr do fim e de seus meios, com um ato dirigido por ela mesma, com o pôr teleológico, a consciência ultrapassa a simples adaptação ao ambiente o que é comum também àquelas atividades dos animais que transformam objetivamente a natureza de modo involuntário - e executa na própria natureza modificações que, para os animais, seriam impossíveis e até mesmo inconcebíveis (LUKÁCS; 2013; 63).

E continua:

A peculiaridade da alternativa aparece ainda mais plasticamente num nível um pouco mais desenvolvido, isto é, não só quando a pedra é escolhida e usada como instrumento de trabalho, mas, em vez disso, para que se torne um melhor meio de trabalho, é submetida a um ulterior processo de elaboração (LUKÁCS; 2013; 71).

\section{(C) ETD-Educação Temática Digital Campinas, SP v.19 $\quad$ n.1 $\quad$ p. 258-282 jan./mar. 2017}


Como consequência dessa capacidade, está posta o germe da liberdade e possibilidade de emancipação humana. Apesar de Lukács ressaltar que:

Deve-se sublinhar ainda, aqui, que esse ente, no trabalho, é sempre algo natural e que essa sua constituição natural jamais pode ser inteiramente suprimida. Por mais relevantes que sejam os efeitos transformadores do pôr teleológico das causalidades no processo de trabalho, a barreira natural só poderá retroceder, jamais desaparecer inteiramente; isso é válido tanto para o machado de pedra quanto para o reator atômico (LUKÁCS; 2013; 73).

E conclui afirmando que:

\begin{abstract}
com isso expusemos apenas um lado da alternativa. Por mais precisa que seja a definição de um campo respectivo, não se elimina a circunstância de que no ato de alternativa está presente o momento de decisão, de escolha, e que o "lugar" e o órgão de tal decisão sejam a consciência humana; e é exatamente essa função ontologicamente real que retira, do caráter de epifenômeno em que se encontravam, as formas da consciência animal totalmente condicionadas pela biologia. Por isso, em certo sentido, poder-se-ia falar do germe ontológico da liberdade, liberdade que cumpriu e ainda cumpre um papel tão importante nas disputas filosóficas acerca do homem e da sociedade (LUKÁCS; 2013; 77)
\end{abstract}

O conjunto aqui apresentado permite Lukács legitimar a auto constituição do ser social pelo ato de trabalho no autêntico devir-ser do homem ao homem.

O trabalho é a categoria que permeia os principais traços do ser social, neste aspecto, Lukács ao apresentar o pôr teleológico como realizável apenas na atividade de trabalho, demonstrou como neles "já estão contidos in nuce", tanto em suas formas gerais como decisivas, "problemas que em estágios superiores do desenvolvimento humano se apresentam de forma mais, generalizada, desmaterializada, sutil e abstrata e que por isso aparecem depois como os temas centrais da filosofia" (LUKÁCS; 2013; 82-3).

Neste processo, Lukács expões o surgimento do pôr teleológico secundário, ou seja, a capacidade de convencimento de um homem ou um coletivo de homens por outros homens a desenvolverem trabalhos traçados de forma externa a eles.

Esse problema aparece logo que o trabalho se torna social, no sentido de que depende de cooperação de mais pessoas, independente do fato de que já esteja presente o problema do valor de troca ou a cooperação tenha apenas como objetivo os valores de uso. Por isso, esta segunda forma de pôr teleológico, no qual o fim posto é imediatamente um pôr do fim por outros homens, já pode existir em estágios muito iniciais (LUKÁCS; 2013; 83).

(C) ETD-Educação Temática Digital Campinas, SP v.19 $\quad$ n.1 $\quad$ p. 258-282 jan./mar. 2017 
A partir do desenvolvimento do trabalho e das subsequentes formações sociais, os homens passam, não de forma mecânica, mas de maneira simultânea a desenvolver outras categorias fundamentais ao ser, como a linguagem e o pensamento. Estas são necessárias a estruturação da vida social produtiva, e já são categorias inteiramente sociais, pois, o homem que comunica, precisa comunicar sobre algo. Isto, mantém a prioridade ontológica do trabalho e não altera, em nenhum momento, sua condição de categoria central no processo de desenvolvimento da vida social. "É por isso que julgamos correto ver no trabalho o modelo de toda a práxis social, de qualquer conduta social ativa" (LUKÁCS; 2013; 83).

Sobre outra perspectiva, Lukács, retoma o problema entre teleologia e causalidade e apresenta o conhecimento contemplativo (o desenvolvimento de teoria) como produto do processo da teleologia no aspecto universal. Para isso, Lukács retoma o debate entre trabalho e ciência, com isso, ele lança luz a necessidade de o conhecimento romper as fronteiras da concepção matemática e tenta transpor o campo meramente ideológico, ou seja, ele confronta a posição neopositivista em sua consideração sobre a prática ser o único critério da ciência.

A essa forma de captar a essência do processo ontológico pelo qual o homem passa da condição de ser biológico ao ser social é o nó que as filosofias idealistas não foram capazes de desatar. Pois se mostraram incapaz de apreender e compreender as relações ontológicas originárias, o que conduziu esse pensamento a se estruturar "metodologicamente, em última análise, no fato de se contentar em analisar, em termos gnosiológicos ou lógicos", se detendo a tomar somente as "categorias mais desenvolvidas, mais espiritualizadas, mais sutis" (LUKÁCS; 2013; 100). Por outro lado, se ignorou os complexos originários que possibilitam se alcançar a gênese ontológica, "desse modo, são apenas consideradas as formas de práxis social que se acham mais afastadas do metabolismo da sociedade com a natureza" (LUKÁCS; 2013; 100), fato esse, que desvia completamente a atenção às mediações, que guardam em si alto nível de complexidade, e mediam a vinculação entre o momento originário e o momento mais desenvolvido. Da mesma forma, nesse percurso, ocorre a construção de antíteses entre esses momentos. Como efeito, se tem nas abordagens idealistas, no que concerne a esse problema, o desaparecimento em sua totalidade das especificidades do ser. O que se coloca no lugar, é uma construção artificial é "uma esfera desprovidas de raízes do dever-ser (do valor)" (LUKÁCS; 2013; 100) que na sequência dessas elaborações, é confrontada a uma forma de puramente natural do homem.

(C) ETD-Educação Temática Digital Campinas, SP v.19 $\quad$ n.1 $\quad$ p. 258-282 jan./mar. 2017 
Em oposição a essa forma de apreender e compreender a realidade do ser social, apresenta-se o materialismo vulgar, que, apesar de se opor as formas idealista, incorre no erro de simplesmente ignorar o papel do dever-ser no ser social e procurar interpretar toda essa esfera segundo o modelo de pura necessidade natural. Isso contribui muito para confundir esse complexo de problemas ao produzir, nos dois polos, uma fechitização dos fenômenos contraposta quanto ao conteúdo e ao método, mas de fato vinculadas entre si (LUKÁCS; 2013; 100).

Lukács entende que para se "compreender bem a gênese inquestionável, segundo nosso modo de ver, do dever-ser a partir da essência teleológica do trabalho", é necessário retornar ao que já foi exposto sobre o próprio trabalho enquanto modelo de toda a práxis social, "ou seja, que entre o modelo e as suas sucessivas e mais complexas variantes há uma relação de identidade de identidade e não identidade". Isso demonstra que na essência ontológica do dever-ser no trabalho, com certeza o homem que se põe a trabalhar não apenas determina à sua maneira de se comportar nessa atividade, como também, a sua forma de comportar-se no que se refere ao seu-em-si como sujeito que atua no interior do ato de trabalhar. Esse, no entanto, é o momento em que se consolida o metabolismo envolvendo o homem e a natureza. O complexo envolvendo a realização do pôr do fim (objeto), da elaboração e utilização dos meios para se alcançar o primeiro, influem de maneira determinista na constituição da essência que coloca o comportamento humano em patamares subjetivos. "E, sem dúvida, também do ponto de vista do sujeito um trabalho só pode ter êxito quando realizado com base numa intensa objetividade, e desse modo a subjetividade, nesse processo, tem que desempenhar um papel produtivamente auxiliar". Isto não elimina, ou quer dizer, que as qualidades e capacidades do sujeito não exerçam influência importante quando o homem está imerso no processo de trabalho tanto de forma "intensiva como extensivamente". Todavia, não se pode retirar do horizonte o fato de que "todas as capacidades do homem que são mobilizadas são sempre orientadas, essencialmente, para o exterior, para a dominação fática e transformação material do objeto natural através do trabalho". Este é o momento, que se verifica pela primeira vez no trabalho, o autodomínio do homem possibilitado através do dever-ser, isso o permite apreender com mais clareza que a "sua compreensão sobre as suas inclinações e hábitos etc. espontaneamente biológicos são regulados e orientados pela objetividade desse processo". Esta condição, a partir de sua essência, se constitui através da existência natural do objeto, dos meios desenvolvidos para se alcançar os fins postos, etc. no interior do processo de trabalho. "Se quisermos conceber corretamente o lado do dever-ser que, no

\section{(C) ETD-Educação Temática Digital Campinas, SP v.19 $\quad$ n.1 $\quad$ p. 258-282 jan./mar. 2017}


trabalho, age sobre o sujeito, modificando-o, é preciso partir dessa objetividade como reguladora (LUKÁCS; 2013; 104).

No caso de que os fins teleológicos traçados tenham por objetivo influenciar outros homens a realizarem o pôr, "a subjetividade de quem põe adquire um papel qualitativamente diferente", o que implica, que ao final desse processo, as relações sociais entre os homens sofrem uma autotransformação do homem que trabalha já que estas se tornam "um objeto imediato de pores teleológicos, cujo caráter é um dever-ser. Naturalmente, esses pores não se diferenciam apenas qualitativamente daquelas formas de dever-ser que contamos no processo de trabalho". Contudo, Lukács ressalta que as diferenças qualitativas aqui expressas, não deveriam, como ocorre no pensamento idealista, lógico e gnosiológico, ocultar o "fato fundamental como de que se trata, em todos os casos, de relações do dever-ser, de atos nos quais não é o passado, na sua espontânea causalidade, que determina o presente, mas ao contrário, é a tarefa do futuro, teleologicamente posta o princípio determinante da práxis social" (LUKÁCS; 2013; 105).

Retomando categorias essências ao ser, Lukács demonstra o afastamento do sujeito do objeto com a criação da linguagem. Por exemplo, a linguagem, nesse caso, se difere da identificada nos outros animais pela capacidade de se dizer algo a alguém sobre um determinado objeto, essa comunicação tem em si uma carga sobre o acumulo da vida social. Ao trabalhar o homem modifica sua natureza e constitui o domínio consciente de si mesmo. Isto, é o que Lukács considera uma consciência verdadeiramente humana. Isso quer dizer que não se trata de um epifenômeno biológico como nas demais espécies da natureza, mas já uma condição humana/social. Lukács rebate a confusão idealista em torno da independência da consciência e da alma em relação ao corpo. Essa confusão está posta na polemica entre os níveis ontológico e axiológico e provem da necessidade em se atribuir sentido à vida, que conforme o autor não tem sentido, ou melhor dizendo, está sobre as condições existentes no acaso. Novamente a questão da liberdade pela capacidade de decisão aparece como resposta a tese idealista e compreensão adequada da realidade humana.

Para Lukács, as formas pré-marxianas de apreensão e compreensão da liberdade não dão conta da complexidade que o tema envolve. Isso está relacionado a forma de compreensão entre necessidade e liberdade. Que no campo do idealismo, tem sua essência distorcida na incompreensão em torno da submissão da teleologia como um momento fundamental para o trabalho e mediação que conduz o ser. Para os idealistas, essa

(C) ETD- Educação Temática Digital Campinas, SP $\quad$ v.19 $\quad$ n.1 $\quad$ p. 258-282 jan./mar. 2017 
possibilidade está na ideia, na razão humana. O que eles não apreendem e compreendem, é que esse momento fundamental, está posta na concretude da realidade, dessa maneira, se torna social a sua condição de dominar cada vez mais as forças da natureza a partir do conhecimento que constrói na realidade em transformação pelo ato de trabalho, de objetivação, pelo ato de se pôr no mundo do ser social. Ao contrário, no caso idealista, a teleologia é generalizada como motor da natureza ou da história e cria um obstáculo, uma cegueira, como chama Hegel em relação a realidade como campo concreto da realização do pôr e da dupla transformação que conduz a possibilidade de alcance da liberdade pelo acumulo de conhecimento das leis da natureza e a "possibilidade proporcionada por ele de fazer com que elas atuem, conforme um plano, em função de determinados fins" (ENGELS apud LUKÁCS; 2013; 145).

\section{A REFLEXÃO POLÍTICA MARXIANA: A CRÍTICA DA POLÍTICA; A REVOLUÇÃO SOCIAL.}

A produção teórica, de Karl Marx, forma um todo coeso, que se reafirma em suas concepções essenciais a cada desenvolvimento. O que significa dizer que não há na obra marxiana uma contraposição entre as formulações de juventude e as formulações da maturidade.

O "Jovem Marx" realiza os lineamentos de sua elaboração filosófica e científica com asserções fundamentais que mais tarde serão levadas a desenvolvimento, e que assinalam a unicidade estrutural de seu pensamento. Portanto, a reflexão política marxiana toma corpo desde os primeiros escritos.

A política é, segundo Marx, uma atividade meio, datada historicamente e instrumental. É algo que há de ser superado. Esta concepção da política recusa o entendimento de que ela constitui uma dimensão do humano e do social de forma permanente e estrutural. Marx recusa as elaborações que se pautam pela busca da perfectibilidade da política compreendida como algo inerente à essência do social. Portanto, finalidade última da objetivação plena do ser social. A finalidade política é sempre parcial e inacabada frente a possibilidade humana da emancipação das condições materiais que envolvem a apropriação privada dos frutos do trabalho humano.

A concepção da política em Marx é expressão cabal do matrizamento ontológico de sua teoria social. $\mathrm{O}$ que significa dizer que a realidade objetiva decorrente da atividade

(C) ETD-Educação Temática Digital Campinas, SP v.19 $\quad$ n.1 $\quad$ p. 258-282 jan./mar. 2017 
humana sensível é determinante nas suas formulações como podemos verificar no seguinte trecho da Ideologia Alemã:

Os pressupostos de que partimos não são arbitrários, nem dogmas. São pressupostos reais de que não se pode fazer abstração a não ser na imaginação. São os indivíduos reais, sua ação e suas condições materiais de vida, tanto aquelas por eles já encontradas, como as produzidas por sua própria ação. Estes pressupostos são, pois, verificáveis por via puramente empírica. O primeiro pressuposto de toda história humana é naturalmente a existência de indivíduos humanos vivos (...) O fato, portanto, é o seguinte: indivíduos determinados, que como produtores atuam de um modo também determinado, estabelecem entre sí relações sociais e políticas determinadas. É preciso que, em cada caso particular, a observação empírica coloque necessariamente em relevo - empiricamente e sem qualquer especulação ou mistificação - a conexão entre a estrutura social e política e a produção. A estrutura social e o Estado nascem constantemente do processo de vida de indivíduos determinados, mas destes indivíduos não como podem aparecer na imaginação própria ou alheia, mas tal como realmente são, isto é, tal e como atuam e produzem materialmente e, portanto, tal e como desenvolvem suas atividades sob determinados limites, pressupostos e condições materiais, independentes de sua vontade. (MARX, 2007: 86-87).

Para Marx, (2010:40) "onde o Estado político já atingiu sua verdadeira forma definitiva, o homem leva, - não só no plano do pensamento, da consciência -, mas também no plano da realidade, na vida concreta, uma dupla vida: uma celestial e outra terrena", "a vida na comunidade política, na qual ele se considera um ente comunitário, e a vida na sociedade burguesa", em que atua como particular; considera outros homens como meios, degrada-se a si próprio como meio e converte-se em joguete de poderes estranhos.

O Estado político conduz-se em relação à sociedade civil de modo tão espiritualista como o céu em relação à terra (...) "No Estado, onde o homem é considerado como um ser genérico, ele é um membro imaginário de uma soberania imaginária", acha-se despojado de sua vida individual e real e dotado de uma generalidade irreal.(Marx, 2010:40-41).

Nessa ordem de reflexões a revolução política difere da revolução social. A revolução política promove a emancipação política, não ainda a emancipação humana. Diz Marx a este respeito:

a emancipação política de fato representa um grande progresso; não chega a ser a forma definitiva da emancipação humana em geral, mas constitui a forma definitiva da emancipação humana dentro da ordem mundial vigente até aqui. Que fique claro: estamos falando aqui de emancipação real, de emancipação prática.(Marx, 2010:41).

(C) ETD- Educação Temática Digital Campinas, SP $\quad$ v.19 $\quad$ n.1 $\quad$ p. 258-282 jan./mar. 2017 
A emancipação política não é o modo radical e isento de contradições da emancipação humana ao emancipar-se politicamente, o homem o faz por meio de um subterfúgio, através de um meio, mesmo que seja um meio necessário. A questão da revolução, em Marx, aponta sempre para a emancipação humana. Para as possibilidades de autoconstrução infinita do homem através da atividade humana sensível, da práxis transformadora.

Nos textos: Sobre a Questão Judaica de 1843 e Glosas Críticas Marginais ao Artigo "O Rei da Prússia e a Reforma Social" de um Prussiano de 1844, Karl Marx apresenta contribuições significativas para o entendimento da emancipação política e da emancipação humana e o que elas representam em termos concretos.

De forma inequívoca, Marx, considera que a emancipação política é limitada a um projeto democrático-burgês, da sociedade de direitos e a emancipação humana deve ser o telos de uma efetiva emancipação humana. A emancipação política é parcial e significa a manutenção da sociedade capitalista, ou seja, da lógica do capital e de todas as suas mazelas e barbáries. Portanto, a emancipação política por mais aperfeiçoada que seja jamais produzirá a liberdade efetiva para o proletariado. A liberdade efetiva do proletariado está condicionada a sua universalização enquanto classe, ou seja, a sua extinção total enquanto classe é condition sine qua non da liberdade humana plena. O projeto do proletariado deve buscar a emancipação humana. Isso significa em termos inequívocos e inegociáveis, vislumbrar a possibilidade e a necessidade de uma revolução social, tendo em vista a substituição da sociabilidade capitalista pela sociabilidade comunista.

Marx no texto, Glosas Críticas Marginais ao Artigo "O Rei da Prússia e a Reforma Social" de um Prussiano, aponta pela primeira vez para o protagonismo do proletariado no processo revolucionário, com vista à emancipação humana. "O proletariado proclama, de modo claro, cortante, implacável e poderoso, o seu antagonismo com a sociedade da propriedade privada." Polemizando com Arnold Ruge neste texto sobre a revolta dos tecelões da Silésia, Marx, inequivocamente diferenciou o proletariado da burguesia, a emancipação humana da política e a revolução social da política. Para ele, a revolta dos tecelões superou todas as outras revoltas anteriores dos trabalhadores, pois trouxe de forma lúcida o antagonismo entre burguesia e proletariado.

(C) ETD-Educação Temática Digital Campinas, SP v.19 $\quad$ n.1 $\quad$ p. 258-282 jan./mar. 2017 
Marx ressalta a importância da revolta dos tecelões nos seguintes termos:

a revolta silesiana começa exatamente lá onde terminam as revoltas dos trabalhadores franceses e ingleses, isto é, na consciência daquilo que é a essência do proletariado. A própria ação traz este caráter superior. Não só são destruídas as máquinas, essas rivais do trabalhador, mas também os livros comerciais, os títulos de propriedade, e enquanto todos os outros movimentos se voltavam primeiramente contra o senhor da indústria, o inimigo visível, este movimento volta-se também contra o banqueiro, o inimigo oculto. Enfim, nenhuma outra revolta de trabalhadores ingleses foi conduzida com tanta coragem, reflexão e duração (MARX, 1995:8).

Marx também expressa a contradição entre o projeto do proletariado e o da burguesia pela contradição entre o político e o social. A luta do proletariado deve ser social, pois a política não altera a sua condição material. Assim, era imperativo sair do ponto de vista político para poder imprimir uma transformação radical na sociedade. Isso significa, que a luta do proletariado não era dirigida para o conquista do poder político (o Estado), mas para sua supressão, pela sua extinção já que a sua existência implicava (e implica) a manutenção da exploração do homem pelo homem.

Quanto mais poderoso é o Estado maior os males sociais. O intelecto político é político exatamente na medida em que pensa dentro dos limites da política. Quanto mais agudo ele é, quanto mais vivo, tanto menos é capaz de compreender os males sociais.

Quanto mais unilateral, isto é, quanto mais perfeito é o intelecto político, tanto mais ele crê na onipotência da vontade e tanto mais é cego frente aos limites naturais e espirituais da vontade e, consequentemente, tanto mais é incapaz de descobrir a fonte dos males sociais.

Na compreensão de Marx, pela análise do processo histórico, o proletariado tem que buscar outro tipo de revolução, pois nos países em que a revolução política tinha sido concluída com a sua efetiva participação, as suas condições de vida não haviam melhorado, pelo contrário, o pauperismo generalizava-se.

Por isso, o proletariado não deveria pensar nos marcos da revolução política, que representa os interesses da burguesia. Nesse sentindo afirmou:

\author{
(C) ETD-Educação Temática Digital Campinas, SP v.19 n.1 p. 258-282 jan./mar. 2017
}




\begin{abstract}
Já demonstramos ao "prussiano" quanto o intelecto político é incapaz de descobrir a fonte da miséria social. Apenas mais uma palavra sobre essa sua concepção. Quanto mais evoluído e geral é o intelecto político de um povo tanto mais o proletariado - pelo menos no início do movimento - gasta suas forças em insensatas e inúteis revoltas sufocadas em sangue. Uma vez que ele pensa na forma da política, vê o fundamento de todos os males na vontade e todos os meios para remediá-los na violência e na derrocada de uma determinada forma de Estado. Demonstração: as primeiras revoltas do proletariado francês. Os operários de Lyon julgavam perseguir apenas fins políticos, ser apenas soldados do socialismo. Deste modo, o seu intelecto político lhes tornou obscuras as raízes da miséria social, falseou o conhecimento dos seus objetivos reais e, deste modo, o seu intelecto político enganou o seu instinto social. (MARX, 1995: 8-9).
\end{abstract}

A revolução social perspectiva a revolução humana. O proletariado, por representar a possibilidade de perda total de sua humana-parcialidade seria o sujeito da emancipação humana, ator da revolução social. Protagonista da plena humanidade, da universalidade do humano. Protagonista, portanto, da objetivação plena do homem no mundo.

\title{
Enfim!
}

A revolução social se faria em determinadas condições e de determinadas maneiras ditadas pela realidade. Em relação ao programa extraído da ata do congresso socialista de Gotta, realizado em maio de 1875, Marx foi interrogado em 1878, numa entrevista ao Chicago Tribune:

- "Pergunta: Este programa é aplicável unicamente à Alemanha e a mais um ou dois outros países?"

- Marx: "Extrair de um programa apenas essas conclusões seria desconhecer as atividades do movimento. Numerosos pontos deste programa não tem a menor significação fora da Alemanha. A Espanha, a Rússia, a Inglaterra e a América do Norte têm seus próprios programas particulares adaptados às suas próprias dificuldades. O único ponto comum é o objetivo final."

- "Pergunta: E esse objetivo é o poder operário?"

- Marx: "É a emancipação dos trabalhadores". (CHASIN, 1990)

(C) ETD-Educação Temática Digital Campinas, SP v.19 $\quad$ n.1 $\quad$ p. 258-282 jan./mar. 2017 
Por tudo o que foi dito, emancipação dos trabalhadores parece ser aqui emancipação humana. A revolução humana, universal, provavelmente não se realizaria na revolução política, mas na revolução social.

\section{A EMANCIPAÇÃO DA POLÍTICA PELA EMANCIPAÇÃO SOCIAL: A REVOLUÇÃO RADICAL.}

Marx nos apresenta pela primeira vez, em sua tese doutoral, o princípio epicurista, da política e do estado como a realização da racionalidade humana. Nesse primeiro momento, nos apresenta o espaço político como uma instância indispensável do controle das contraposições societárias antagônicas, em outros termos, há uma compreensão "ontopositiva" da política. Portanto, nesse momento, Marx percebe a presença de uma classe progressista da história, e escreve invocando essa classe a uma "ontopositividade" da política. Isso denota que nesse momento, Marx buscava a resolução dos impasses sociais através do recurso ao "formato racional do estado moderno e da universalidade do direito" (CHASIN, 2000a, p.133).

É em um texto pouco conhecido: "observaciones sobre la reciente instrución prussiana acerca de la censura" (MARX, 1982) que Marx caracteriza a razão jurídica e política como elementos indissolúveis do homem. A reconfiguração do padrão reflexivo que o eleva à uma nova compreensão da política acontece entre maio e setembro de 1843 , como verificamos em suas correspondências com Arnold Ruge. Nesse período, Marx se desliga da Gazeta Renana, cria os Anais Franco-Alemães e, aproveitando sua "lua de mel", instala seu gabinete de estudos em Kreuznach .

Nessa guinada ontológica, a qual Marx jamais abandonará, há três textos fundamentais: "Sobre a questão judaica", de outubro de 1843; "Para a crítica da filosofia do direito de Hegel - Introdução", fins de 1843 e inicio de 1844 publicados originalmente nos Anais Franco-Alemães; e as "Glosas Críticas Marginais ao Artigo 'O Rei da Prússia e a Reforma Social', Por um Prussiano", de agosto de 1844, publicados originalmente nos números 63 e 64 do Vorwärts! no qual rompe definitivamente com Arnold Ruge, o último neo-hegeliano com quem ainda mantinha contato.

A concepção contida na Ideologia Alemã de que o homem é uma forma específica de ser, e dada sua especificidade ontológica é compulsoriamente levado a forjar suas condições de existência, pode ser vista em "Para a Crítica da Filosofia do Direito de Hegel -
(C) ETD- Educação Temática Digital
Campinas, SP
v.19 n.1
p. $258-282$
jan./mar. 2017 
Introdução". Nesse texto, o ato fundador da sociedade civil deixa de ser a política para ser o trabalho em sua dimensão ontológica. A política é colocada como figura transitória a ser naturalmente superada no momento subsequente imediato do evolver da porção avançada da humanidade a caminho da emancipação. Desse modo, Marx diferencia a revolução política (parcial) da revolução radical (emancipação social) tendo em vista a emancipação humana objetivando a sociabilidade comunista. Para ele, naquele momento,

\begin{abstract}
O sonho utópico da Alemanha não é a revolução radical, a emancipação humana universal, mas a revolução parcial meramente política, que deixa de pé os pilares do edifício. Qual a base de uma revolução parcial? Apenas esta: uma seção da sociedade civil emancipa-se e alcança o domínio universal: uma determinada classe empreende a partir da sua situação particular uma emancipação geral da situação. Tal classe emancipa a sociedade como um todo, mas só no caso de a totalidade da sociedade se encontrar na mesma situação que esta classe. [...] Nenhuma classe da sociedade civil consegue desempenhar este papel a não ser que possa despertar, em si e nas massas, um momento de entusiasmo em que se associe e misture com a sociedade em liberdade, se identifique com ela e seja sentida e reconhecida como a representante geral da referida sociedade. (MARX, 2005, p.154).
\end{abstract}

As posições iniciais que abordam a política e seu atributo jurídico como uma estrutura capaz de posicionar os homens em condições de igualdade na medida em que o estado poderia eliminar as distinções estabelecidas por nascimento, posição social, educação ou profissão, decretando-as como "não políticas", cai por terra em "Sobre a questão judaica".

Marx demonstra que o estado em sua essência ontológica aparece permitindo que a propriedade privada, a educação e a profissão, manifestando sua natureza particular, longe de abolir essas diferenças, as legitimam, pois o estado só existe na medida em que as pressupõe. Em síntese, o estado e a política só fazem valer sua universalidade na existência da desigualdade.

Portanto, para Marx (apud CHASIN, 2000a, p.145), nessa metáfora poderosa, a sociedade civil se contrapõe à política, id est, a sociedade civil não possui a política como atributo ineliminável: "[...] o estado político, em relação à sociedade civil, é precisamente tão espiritual como o céu em relação à terra."

$\mathrm{Na}$ perspectiva parcial da emancipação política, encontramo-nos com o sufrágio universal do estado de direito, que separa o homem em indivíduo privado e cidadão. Assim,

(C) ETD-Educação Temática Digital Campinas, SP v.19 $\quad$ n.1 $\quad$ p. 258-282 jan./mar. 2017 
os chamados direitos do homem constituem apenas os direitos de um membro da sociedade civil, isto é, do homem separado dos outros homens e da comunidade.

A esse "homem cindido" separado de si e dos outros, profundamente desumanizado pela materialidade imposta pela sociedade civil capitalista, Marx denomina indivíduo circunscrito, pois cada homem vê no outro não a realização do seu gênero, o humano, mas a limitação da sua própria liberdade. Como se vê na conhecida Declaração dos Direitos do Homem de 1791, a liberdade consiste em poder fazer tudo o que não prejudique outrem. Desse modo, na formulação jurídica dos direitos humanos, o homem está longe de ser concebido como um ser genérico, mas, ao contrário, a própria vida genérica aparece como sistema externo ao indivíduo, como limitação de sua independência originária.

Marx vislumbra na revolução social a saída desse impasse. Essa revolução social deveria ter como protagonista a classe que no século XIX fora o produto mais autêntico da grande indústria, como denominado na "Crítica ao Programa de Gotha": o proletariado.

O proletariado não é senão a classe capaz de levar a cabo a emancipação humana enquanto uma esfera universal "por seus sofrimentos", por sorte que o proletariado não assuma interesses de classe, mas a identificação com o ser humano genérico. Vejamos:

Onde existe então, na Alemanha, a possibilidade positiva da emancipação? Eis a nossa resposta: na formação de uma classe que tenha cadeias radicais, de uma classe da sociedade civil que não seja uma classe da sociedade civil, de um estamento que seja a dissolução de todos os estamentos, de uma esfera que possua caráter universal porque seus sofrimentos são universais e que não exige uma reparação particular porque o mal que lhe é feito não é um mal particular, mas o mal em geral, que já não possa exigir um título histórico, mas apenas o título humano; de uma esfera que não se oponha às consequências particulares, mas que se oponha totalmente aos pressupostos do sistema político alemão; por fim, de uma esfera que não pode emancipar-se a si mesma nem a se emancipar de todas as outras esferas da sociedade, sem emancipá-las a todas - o que é, em suma, a perda total da humanidade, portanto, só pode redimir-se a si mesma por uma redenção total do homem. A dissolução da sociedade, como classe particular, é o proletariado. (MARX, 2005;155-156).

Como vimos anteriormente nesse artigo, esses lineamentos da crítica da razão política iniciada nos "Manuscritos de Kreuznach" são repostos por Marx nas "Glosas críticas marginais ao artigo 'O Rei da Prússia e a Reforma Social', Por um Prussiano". No artigo de Ruge, a sublevação dos silesianos fracassara por não possuir uma "alma política". Para Marx, ao contrário, não se trata de "alma política", isto é, de substituir um governo por outro, mas de abolir a própria política. Uma revolução social sem alma política é impossível,

(C) ETD- Educação Temática Digital Campinas, SP v.19 $\quad$ n.1 $\quad$ p. 258-282 jan./mar. 2017 
pois, mesmo que a revolução social simbolizasse a sublevação num único distrito fabril, ela engendra um protesto do homem contra a vida desumanizada e, além de tudo, toda revolução dissolve a velha sociedade, e assim considerada é uma revolução social. Novamente:

\begin{abstract}
O entendimento político é político precisamente porque pensa dentro dos limites da política [...] e o princípio da política é a vontade.[...] Quanto mais desenvolvido e generalizado se acha o entendimento político de um povo, mais o proletariado desperdiça suas energias - pelo menos no início do movimento - em revoltas irrefletidas, estéreis, que são afogadas em sangue. Ao pensar sob forma política, divisa o fundamento de todos os males na vontade e os meios para os remediar na força e na derrubada de uma determinada forma de governo. Temos a prova disso nas primeiras explosões do proletariado francês. [...] 0 entendimento político lhes ocultava as raízes da penúria social, falsificada a compreensão de sua verdadeira finalidade; o entendimento político enganava pois, o seu instinto social. (MARX apud CHASIN, 2000a, p.155-156).
\end{abstract}

Na modernidade ocorre uma cisão entre Estado e sociedade civil, entre os âmbitos político e social, público e privado. Momento histórico em que o poder político será necessariamente afastado do social se colocando acima deste, e o Estado será sempre o Estado de uma parte da sociedade civil que se emancipa e se sobrepõe às outras.

Um Estado que representasse o poder da sociedade civil como um todo desapareceria por ser inútil. É neste sentido que superar a política seria, pois, superar as próprias classes sociais. A sociedade civil é o lugar onde os homens realizam o seu direito privado, onde o direito humano passa a ser o direito egoísta do indivíduo solitário. E o público passa a ser o guardião do privado.

Na modernidade, o indivíduo passa a se contrapor à coletividade - a sociedade organizada pelo capital contrasta com cada um dos homens. O estado no modo de produção capitalista materializa uma oposição radical entre o público (social) e o privado (particular). Essa oposição produz uma mutilação da dimensão propriamente humana do homem. Porque o homem só se faz homem em sociedade, na relação com outros homens.

Segundo Marx o indivíduo só é indivíduo na coletividade. O Estado político acabado se configuraria como o "céu" da sociedade civil. A revolução humana, universal, provavelmente não se realizaria na emancipação política, mas pela emancipação social. Para se efetivar a revolução seria preciso determinadas condições materiais objetivas que organizariam e propiciariam as condições subjetivas. Nessa ordem de reflexões, a história hoje nos comprovaria como as condições materiais são absolutamente necessárias.

(C) ETD-Educação Temática Digital Campinas, SP $\quad$ v.19 $\quad$ n.1 $\quad$ p.258-282 jan./mar. 2017 
Tomando como exemplo o ator principal do amplo quadro dos países que amargaram as consequências dos erros de suas revoluções no século XX - a União Soviética - poderíamos concluir que a revolução russa teria atingido o patamar de uma emancipação política efetivada sem a base material necessária, e teria perdido desde logo a condição de efetivar a emancipação social.

O que hoje ocorre mundialmente não seria, portanto, um desmentido de Marx, mas a sua reafirmação: a emancipação social não se realiza sobre um quadro de miséria. Não houve consequentemente, transição para a emancipação social nos países do Leste. A emancipação política por si só não construiria uma ordem social de características novas. Isto caberia à emancipação social - reordenar o quadro de produção e reprodução das bases da existência humana. Assim, diz-nos Marx:

Toda emancipação é a redução do mundo humano e suas relações ao próprio homem. A emancipação política é a redução do homem, por um lado, a membro da sociedade burguesa, a indivíduo egoísta independente, e, por outro, a cidadão, a pessoa moral. Mas a emancipação humana só estará plenamente realizada quando o homem individual real tiver recuperado para si o cidadão abstrato e se tornado ente genérico na qualidade de homem individual na sua vida empírica, no seu trabalho individual, nas suas relações individuais, quando o homem tiver reconhecido e organizado suas "forces propres" [forças próprias] como forças sociais e, em consequência, não mais separar de si mesmo a força social na forma da força política. (Marx, 2010:54).

A propriedade maior da obra de Marx é a de proporcionar uma determinação fundamental para superar as relações sociais vigentes sob o sistema do capital; porém, não só. Pois, os objetivos centrais das tematizações marxianas se colocam no plano do entendimento de como do "macaco" se dá o homem ou, colocado de outra forma, como o homem se humaniza.

Marx nos convida preservar o homem em suas questões fundamentais. Pensar o homem como autoconstrutor, como fazedor de sua própria história, que se eleva ao estatuto de infinito enquanto possibilidade de desenvolvimento humano através do trabalho, da atividade humana sensível, da práxis.

Finalmente, para Marx, a política em sua anatomia originária, só pode existir com o pressuposto de atenuar as contradições inerentes ao modo de produção que separa drasticamente indivíduo e sociedade civil. Atenuante de um modo de produção que

(C) ETD-Educação Temática Digital Campinas, SP v.19 $\quad$ n.1 $\quad$ p. 258-282 jan./mar. 2017 
estabelece como princípio norteador das relações humanas a apropriação privada dos frutos do trabalho humano social.

A revolução deve ser revolução radical. Revolução que se apoia na tomada do poder político pela classe que objetiva a emancipação humana e que elimina no processo desta emancipação todo poder político, portanto, superando-o como condição para realização da plena liberdade humana. É condition sine qua non a essa condição a extinção do capital e do estado. Portanto, a extinção do proletariado enquanto classe social. Portanto, o fim de todas as classes, o advento do comunismo. Essa a realização da utopia, essa a finalidade humana!

\begin{abstract}
Façamos agora a síntese dos resultados: a emancipação dos alemães só é possível na prática se for adotado o ponto de vista da teoria, segundo a qual o homem é para o homem o ser supremo. A Alemanha não conseguirá emancipar-se da Idade Média a não ser que se emancipe ao mesmo tempo das vitórias parciais sobre a Idade Média. Na Alemanha, nenhum tipo de servidão será abolido, se toda a servidão não for destruída. A Alemanha, que é profunda, não pode fazer uma revolução sem revolucionar a partir do fundamento. A emancipação do alemão é a emancipação do homem. A filosofia é a cabeça desta emancipação e o proletariado é o seu coração. A filosofia não pode realizar-se sem a supra-sunção do proletariado, o proletariado não pode supra-sumir-se sem a realização da filosofia. Quando forem cumpridas todas as condições internas, o dia da ressurreição da Alemanha será anunciado com o cantar do galo gaulês. (MARX, 2005:156).
\end{abstract}

Nossa expectativa é que a humanidade um dia ouça esse cantar!

\title{
REFERÊNCIAS
}

CHASIN, J. Marx: a determinação ontonegativa da politicidade. Ensaios AD Hominem, Santo André, t.3, p.129-161, 2000a.

CHASIN, J. O futuro ausente: a conscientização da nova politicidade: Niccolò Machiavelli. Ensaios AD Hominem, Santo André, t.3, p.197-243, 2000b.

LUKÁCS, György. Para uma ontologia do ser social I. Tradução, Carlos Nelson Coutinho, Mario Duayer e Nélio Schneider. São Paulo: Boitempo, 2012.

LUKÁCS, György. Para uma ontologia do ser social II. Tradução, Nélio Schneider, Ivo Tonet, Ronaldo Vielmi Fortes. São Paulo: Boitempo, 2013.

(C) ETD-Educação Temática Digital Campinas, SP v.19 $\quad$ n.1 $\quad$ p. 258-282 jan./mar. 2017 
MARX, K. A questão judaica. São Paulo: Editora Moraes, 1970.

MARX, Karl. Crítica da filosofia do direito de Hegel: 1843. Tradução de Rubens Enderle e Leonardo de Deus. São Paulo: Boitempo, 2005.

MARX, Karl. ENGELS, Friedrich. A ideologia alemã: crítica da mais recente filosofia alemã em seus representantes Feuerbach, B. Bauer e Stirner, e do socialismo alemão em seus diferentes profetas (1845-1846). São Paulo: Boitempo, 2007.

MARX, Karl. Entrevista com o fundador do socialismo moderno - Chicago Tribune, dezembro de 1878. (Apresentação de Bert Andreas). In: CHASIN, J. (Org). Marx hoje. v.1. São Paulo: Ensaio, 1990.

MARX, Karl. Glosas críticas ao artigo: o rei da Prússia e a reforma social de um prussiano. Revista Práxis, Belo Horizonte, n.5, 1995.

MARX, Karl. Manuscritos econômicos-filosóficos. Tradução Jesus Ranieri. São Paulo: Boitempo, 2009.

MARX, Karl. 0 capital: crítica da economia política: livro I: o processo de produção do capital. Tradução, Rubens Enderle. São Paulo:Boitempo, 2013.

MARX, Karl. Observaciones sobre la reciente instrución prussiana acerca de la censura. In: MARX, Carlos, ENGELS, Frederico. Obras fundamentales: Marx - escritos de juventud. México: Fondo de Cultura Econômica, 1982. v. 1.

MARX, Karl. Sobre a questão judaica. Inclui as cartas de Marx a Ruge publicadas nos Anais FrancoAlemães. São Paulo: Boitempo, 2010.

MARX, Karl. Sobre a questão judaica. Tradução Nélio Schneider, [tradução de Daniel Bebsaïd, Wanda Caldeira Brant]. São Paulo: Boitempo, 2010.

\footnotetext{
' Revisão gramatical do texto pela equipe da revista
}

(C) ETD-Educação Temática Digital Campinas, SP v.19 $\quad$ n.1 $\quad$ p. 258-282 jan./mar. 2017 